\title{
First stewards: ecological outcomes of forest and wildlife stewardship by indigenous peoples of Wisconsin, USA
}

\author{
Donald M. Waller ${ }^{1}$ and Nicholas J. Reo ${ }^{2}$
}

\begin{abstract}
Indigenous peoples manage forestlands and wildlife differently than public and private forestland managers. To evaluate ecological outcomes from these differences, we compared the structure, composition, and diversity of Ojibwe and Menominee tribal forests to nearby nontribal forestlands in northern Wisconsin. These indigenous peoples seek to manage forests for mature conditions, accommodate wolves and other predators, and hunt deer to sustain traditional livelihood values. Their forests are often more mature with higher tree volume, higher rates of tree regeneration, more plant diversity, and fewer invasive species than nearby nontribal forestlands. In contrast, nontribal forestlands lost appreciable plant diversity in the 20th century and have failed to regenerate tree species sensitive to deer herbivory. Ensuing shifts in forest composition and wildlife populations have jeopardized the ability of managers to sustain wildlife and meet certification standards on nontribal forestlands. Lessons from tribal forestlands could help improve the sustainable management of nontribal public forestlands.
\end{abstract}

Key Words: carbon storage; deer browse impacts; forest management; indigenous land tenure; indigenous values; tree regeneration

\section{INTRODUCTION}

Indigenous peoples make up over $5 \%$ of the world's population, their territories comprise at least $20 \%$ of the land area of the planet, and these lands host an estimated $80 \%$ of the world's biodiversity (Stevens 2014). The relationships between indigenous land tenure and biological diversity is a challenging area of research, but several studies suggest that indigenous peoples' place-based values, institutions, and practices help promote biodiversity. Indigenous lands often support higher native and rare species richness (Redford and Stearman 1993, Peres 1994, Arcese et al. 2014) and lower rates of deforestation (Nolte et al. 2013, Ceddia et al. 2015). However, beyond a handful of studies looking at biodiversity and land use change, few researchers have looked at the broader ecological outcomes of indigenous land tenure.

Indigenous peoples in Wisconsin manage forestlands and wildlife by merging professional standards of forestry and wildlife practice with their own culturally specific traditional ecological knowledge and land-based values. Although commercial and ecological forestry best-practices are utilized in tribal forestry programs, indigenous communities' own knowledge systems and values have a strong influence. This has often led to distinct forest and wildlife management goals, institutions, and practices (Trosper 2007, Dockry 2012, Reo and Whyte 2012). Indigenous forestry in the United States and Canada has several unique aspects (Bengston 2004). The Cherokee Nation of Oklahoma, for example, plants a diverse suite of culturally significant tree species and favors nonchemical methods of land clearing that promote the growth of food and medicinal plants while protecting harvesters' health (Carroll 2015). Anishnaabe of Shoal Lake in Northwestern Ontario use succession management via landscape burning and timber harvest to promote biodiversity and support local livelihoods (Berkes and Davidson-Hunt 2006). Indigenous forestry outside North America includes managing sacred forest groves that promote bird diversity in Tibet (Brandt et al. 2013) and agri-forestry practices by Yoruba in Nigeria that integrate cash crops and trees, limiting soil erosion and increasing soil fertility (Warren and Pinkston 1998).

Indigenous Nations and nonindigenous forest and wildlife managers generally profess similar goals typically centered around sustaining resource values and yields, biological diversity, and ecosystem productivity despite some differences (Table 1). Do these shared goals lead to similar outcomes on the lands managed by these two groups? Here, we explore that question within the specific context of northern Wisconsin where a mix of private industrial, private nonindustrial, and county, state, and national public forestlands surround four major "Indian reservations," i.e., lands under jurisdiction of Indigenous Nations in the U.S. (Fig. 1A). This study thus fits within existing literature concerning the foundations and outcomes of indigenous forest and wildlife management. Our focus here, however, is to quantify the ecological outcomes of forest and wildlife management and links between the two. That is, have the land-based values and practices of indigenous peoples in Wisconsin led to significantly different ecological conditions on their forestlands relative to neighboring lands? In the discussion, we return to the question of how differences in values and goals contribute to the differences in outcomes we document.

\section{Background}

Ojibwe tribes from what is now Wisconsin, Minnesota, and northern Michigan ceded most of their homelands, over 11 million ha, to the U.S. government in four treaties signed in 1836, 1837,1842 , and 1854 (Kurtz et al. 2015). Federal court decisions in the 1980s affirmed Ojibwe rights to access certain natural resources in these ceded territories. When they began to exercise these treaty rights, however, the tribal citizens were strongly criticized and physically attacked (Gedicks 1993, Nesper 2002). Ongoing altercations (the "walleye wars") involved some who argued that Indigenous Nations and their citizens could not be trusted to manage fish and wildlife populations sustainably. In upholding tribal rights in a 1990 decision, Federal Judge Barbara 
Table 1. Perspectives for managing Wisconsin forestland. For each land base, we list stated goals for managing that land (column two) from the source listed in column one as well as a summary label or statement (column three).

\begin{tabular}{|c|c|c|}
\hline Land base and source & $\begin{array}{l}\text { Excerpts from vision } \\
\text { and goals statements }\end{array}$ & Human-environment perspective/narrative \\
\hline $\begin{array}{l}\text { Sawyer County, Wisconsin } \\
2006 \text { 15-year County Forest Plan }\end{array}$ & $\begin{array}{l}\text { Enable and encourage planned development and management } \\
\text { of the County Forest for optimum production of forest } \\
\text { products together with recreational opportunities, wildlife, } \\
\text { watershed protection, and stabilization of stream flow. }\end{array}$ & $\begin{array}{l}\text { Maximum sustained yield; multiple-use } \\
\text { management }\end{array}$ \\
\hline Northern Highland - American & Forest as a dynamic environment comprising a variety of & Biotic communities and ecosystems providing \\
\hline Legion State Forest 2005 Master Plan & $\begin{array}{l}\text { biological communities that contribute to the diversity of } \\
\text { ecosystems in the region, providing a range of human and } \\
\text { ecological benefits for present and future generations. }\end{array}$ & $\begin{array}{l}\text { human and ecological benefits now and in } \\
\text { future; ecosystem services }\end{array}$ \\
\hline $\begin{array}{l}\text { Chequamegon-Nicolet National } \\
\text { Forest } 2004 \text { Land and Resource } \\
\text { Management Plan }\end{array}$ & $\begin{array}{l}\text { Ensure healthy and sustainable ecosystems and provide } \\
\text { multiple benefits for people within the capability of } \\
\text { ecosystems }\end{array}$ & Ecosystem management \\
\hline $\begin{array}{l}\text { Keweenaw Bay Indian Community } \\
2002 \text { Integrated Resource } \\
\text { Management Plan }\end{array}$ & $\begin{array}{l}\text { To live in harmony while enhancing and sustaining the } \\
\text { resources of the Keweenaw Bay Indian Community for the } \\
\text { Seventh Generation. }\end{array}$ & Deep time sustainability \\
\hline $\begin{array}{l}\text { Lac du Flambeau (LDF) Tribe } \\
\text { Integrated Resource Management } \\
\text { Plan and 2011-2016 Wetland } \\
\text { Management Plan }\end{array}$ & $\begin{array}{l}\text { To protect and restore water quality, watershed condition, and } \\
\text { aquatic/riparian habitat; to protect and preserve the wetlands } \\
\text { and dependent wildlife of the LDF Tribe; to cultivate Indian } \\
\text { arts, crafts, and culture; to administer charity; to protect the } \\
\text { health, security, and general welfare of the LDF Tribe. }\end{array}$ & Traditional values and ecological conditions \\
\hline $\begin{array}{l}\text { Fond du Lac (FDL) Tribe Integrated } \\
\text { Resource Management Plan } 2008\end{array}$ & $\begin{array}{l}\text { Committed to the management, conservation, and } \\
\text { sustainability of the natural resources of the FDL Band to } \\
\text { protect the environment on the Reservation and within its } \\
\text { treaty areas. }\end{array}$ & Traditional values and ecological conditions \\
\hline
\end{tabular}

Crabb clarified that Ojibwe tribes could take up to $50 \%$ of biological resources in cases where harvest quotas are set. For deer, a cap of 900 total animals was set with no more than $50 \%$ of the quota to be taken from any given deer management unit. This cap is far lower than $50 \%$ of the allowable harvest across the deer management units (DMUs) in the ceded territory. A 1991 decision further ruled that although the Ojibwe could not harvest timber commercially, they could gather nontimber goods including maple sap, birchbark, and firewood. Despite concerns that the Ojibwe might overexploit these resources, they have exercised their rights sparingly, leaving these resources "better off ... than they were prior to such involvement" (Busiahn and Gilbert 2011:156).

Today, ceded territories within the Lake States are in mixed ownership, with approximately $43 \%$ public $(16.1 \%$ federal, $16.1 \%$ state, and $10.4 \%$ county), $54 \%$ private, and $3.6 \%$ tribal (Gordon et al. 2013, Kurtz et al. 2015). Tribes now manage natural resources autonomously within their respective reservation boundaries. This has tended to cause tribal forests to diverge from nontribal forestlands over the last century (Steen-Adams et al. 2011). Tribal, state, and federal authorities comanage natural resources, i.e., shared authority and shared responsibility, on public portions of the ceded territories. Natural resource comanagement in the Great Lakes region to date has been primarily focused on discrete fish and wildlife populations (Pinkerton 1989, Busiahn and Gilbert 2011).

Wisconsin forests cover 6.92 million ha including large areas of national, state, and county/school forests $(\sim 8.9 \%, 7.2 \%$, and $14.4 \%$, respectively; Forest Inventory Data 2015$)$. The state and national forests in Wisconsin are managed to sustain biological diversity, healthy forest regeneration, and a nondeclining flow of pulpwood and sawtimber under the Multiple Use Sustained Yield Act of 1960, the National Forest Management Act of 1976, and Wisconsin Forest State Management Guidelines (Wisconsin Department of Natural Resources 2011) as outlined in Table 1. Sustaining diverse, resilient forest ecosystems while generating a steady flow of forest products presents challenges given that landuse legacies and changing forces affect forests at various spatial and temporal scales. Integrating forest management in varying social contexts and economic systems that emphasize different human values and priorities further complicates this task (Ostrom et al. 2007). Forest and wildlife managers use their knowledge of forest ecosystems to address these challenges. Nevertheless, their ability to accurately predict how their management actions will affect the forests they oversee is limited because forests change gradually, monitoring is limited, and studies that assess long-term outcomes of different forest management activities are scarce.

\section{METHODS}

We compared ecological conditions between Indigenous Nations' forested reservations and nearby nontribal lands (Fig. 1) as they have developed over the past century in northern Wisconsin. That is, we tested the hypothesis that the differences in how the Menominee and Ojibwe tribes manage forests and wildlife relative to surrounding lands (summarized above and in Table 1) generate differences in ecological outcomes relative to lands managed by nontribal owners. The largest indigenous forestlands in Wisconsin are the Menominee $\left(917 \mathrm{~km}^{2}\right)$ and three Ojibwe reservations: Bad River $\left(506 \mathrm{~km}^{2}\right)$, Lac du Flambeau $\left(350 \mathrm{~km}^{2}\right)$, and Lac Courtes Oreilles $\left(312 \mathrm{~km}^{2}\right)$. Ecological conditions can only be fairly compared among land bases that are large enough for contrasting patterns of forest and wildlife management to result in different biological and wildlife conditions. In particular, the lands must 
Fig. 1. (A) Map showing the locations of territories ceded to the Ojibwe peoples in the 1800s, current Indian reservations in northern Wisconsin, and the Chequamegon-Nicolet National Forest. These are overlaid on a map showing the distribution of live-tree biomass in this region (which is proportional to forest carbon storage, see text). Note the higher tree biomass evident on the Menominee relative to most lands surrounding it. Tree biomass densities on the other (Ojibwe) reservations more resemble those on nearby lands. Source: 2009 U.S. Forest Service FIA data (Perry et al. 2012). (B) Housing density in northern Wisconsin in 2010 (units $/ \mathrm{km}^{2}$ ). Note lower densities on the Indian reservations. Sources: U.S. Census bureau, Conservation Biology Institute Protected Area Database, Vers. 2, and V. Radeloff SILVIS lab, Univ. of Wisconsin (http://silvis.forest.wisc.edu/maps).
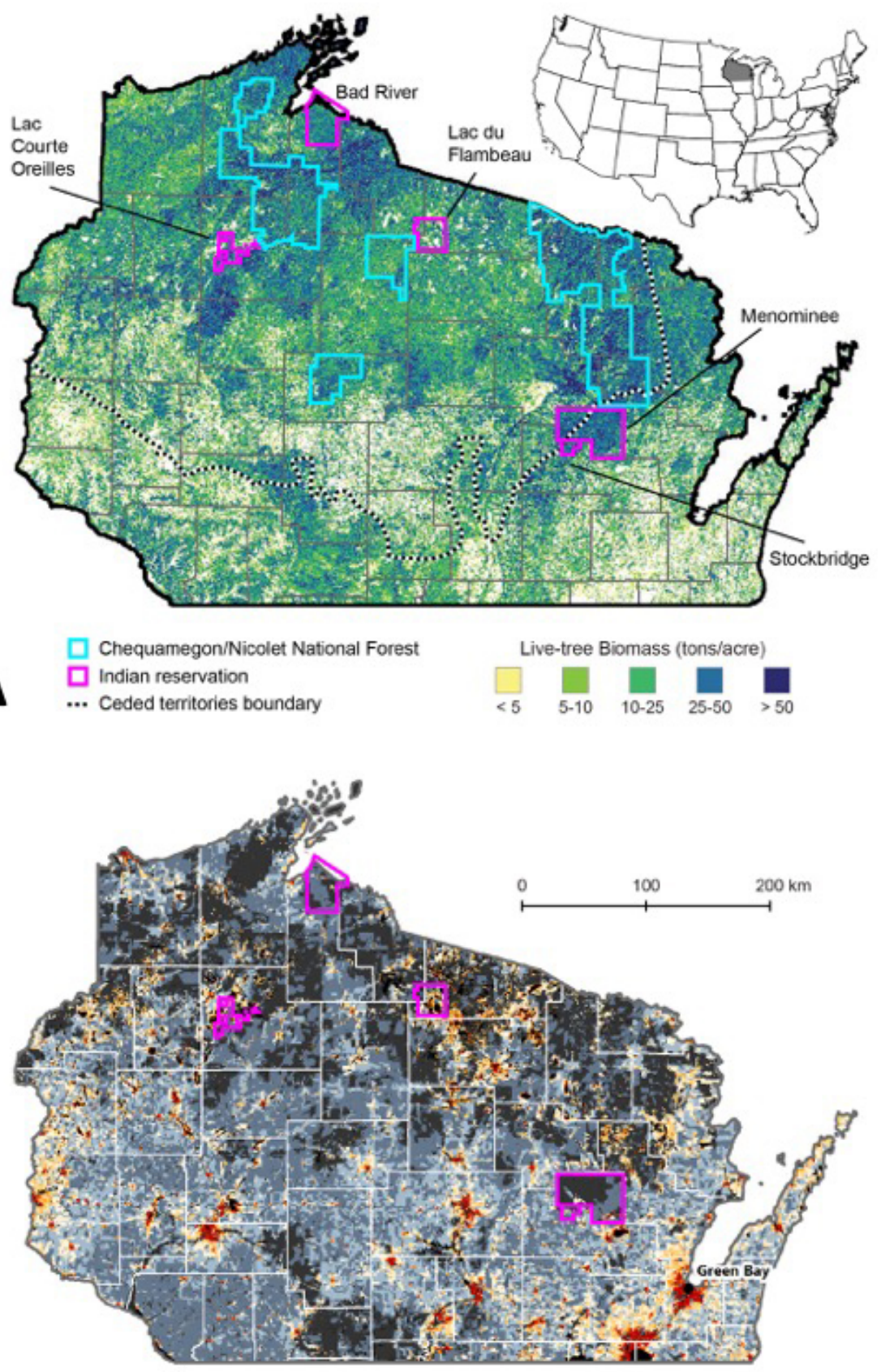

B

$$
\text { Indian reservation }
$$


Table 2. The seven conditions being analyzed and compared between tribal and nontribal lands in northern Wisconsin. Note variation in the lands being compared to tribal lands among these variables and the diverse sources for these data.

\begin{tabular}{|c|c|c|}
\hline Conditions compared & Nontribal areas compared & Source of data \\
\hline Forest type and composition & State and national forests in N. Wisconsin & $\begin{array}{l}\text { Wiscland } 2.0 \text { (http://dnr.wi.gov/maps/gis/ } \\
\text { datalandcover.html) }\end{array}$ \\
\hline $\begin{array}{l}\text { Landscape conditions (house and road density, } \\
\text { etc.) }\end{array}$ & Adjacent nontribal lands & $\begin{array}{l}\text { Satellite photos; } \\
\text { Hammer et al. 2004; U.S. Census Bureau ( } \underline{\text { http:// }} \\
\text { silvis.forest.wisc.edu/maps) }\end{array}$ \\
\hline Forest structure, and biomass/carbon & All other forestland in N. Wisconsin & $\begin{array}{l}\text { U.S. Forest Service FIA data (https://apps.fs.usda. } \\
\text { gov/fia/datamart/datamart.html) }\end{array}$ \\
\hline $\begin{array}{l}\text { White-tailed deer (Odocoileus virginianus) } \\
\text { densities }\end{array}$ & Deer Management Units adjacent to tribal lands & $\begin{array}{l}\text { Wisconsin Department of Natural Resources } \\
2017\end{array}$ \\
\hline $\begin{array}{l}\text { Forest understory diversity and changes in } \\
\text { diversity }\end{array}$ & $\begin{array}{l}\text { High-quality mature forest stands in N. } \\
\text { Wisconsin (mostly public) }\end{array}$ & Rooney et al. 2004, Wiegmann and Waller 2006 \\
\hline Regional patterns of tree regeneration & Other forestlands in N. Wisconsin & $\begin{array}{l}\text { Bradshaw and Waller 2016; U.S. Forest Service } \\
\text { FIA data; Solheim and Waller, unpublished data }\end{array}$ \\
\hline $\begin{array}{l}\text { Survival and growth of Tsuga and Thuja tree } \\
\text { seedlings }\end{array}$ & $\begin{array}{l}\text { High-quality hemlock and cedar forest stands in } \\
\text { N. Wisconsin }\end{array}$ & $\begin{array}{l}\text { Rooney et al. 2000, 2002; Alverson and Waller, } \\
\text { unpublished data }\end{array}$ \\
\hline
\end{tabular}

be large enough to sustain characteristic landscape processes, e.g., patchy intermittent disturbances, movement corridors, and preypredator dynamics. On smaller reservations, differing forest and wildlife practices have less opportunity to generate divergent ecological conditions. Pickett and Thompson (1978) describe this threshold as an ecosystem's "minimum dynamic area" (MDA). Alverson et al. (1994) estimate the MDA in northern Wisconsin to be $\sim 200 \mathrm{~km}^{2}$. Only the four reservations selected exceed this threshold.

To ensure that differences in underlying ecological conditions did not bias our comparisons between tribal and nontribal lands, we first compared forest cover types among ownership classes across the primarily forested landscapes of northern Wisconsin. If forest type differed conspicuously on and off the larger reservations, any other differences we observed could reflect this simple fact rather than differences in management. Divergent trajectories of forest change also tend to emerge only when Indigenous Nations have stewarded their forestlands over several successive decades. Through much of the 19 th and early 20 th centuries, U.S. and state policies interfered with Indigenous Nations' cultural practices and autonomy. Thus, any differences found here between conditions on tribal vs. nontribal lands likely underestimate the greater differences that would have emerged if tribal management had been applied consistently over larger areas and longer periods.

Because the management of forests and wildlife affects many ecological processes and outcomes, we compared a broad set of ecological variables between tribal and nontribal lands in this study (Table 2). Our domain of study was the predominantly forested region of northern Wisconsin north of a line between Minneapolis and Green Bay. We made most comparisons at a geographical scale of about $200+\mathrm{km}^{2}$. This approach allowed us to aggregate and average results across dozens to thousands of sampled sites, increasing reliability and statistical power. We were limited to using the land bases and periods reflected in the particular studies available and the methods they employed (see below and Table 2).

We began our comparison of ecological conditions on tribal vs. nontribal lands by examining patterns of human settlement, land use, and land cover. Landscape conditions like small patch size, patch isolation, the density of edge habitats, and levels of human occupation and use can all adversely affect wildlife populations (Haddad et al. 2015). Roads depress wildlife populations via both direct effects like accidents and by fragmenting and isolating habitats, restricting dispersal and migration (Forman and Alexander 1998, Spellerberg 1998, Trombulak and Frissell 2000). Road, house, and human population densities also reflect a broad range of anthropogenic impacts on ecological conditions and wildlife populations including forest fragmentation (Radeloff et al.2005), rates of losing native species, and invasions by nonnative species (Mortensen et al. 2009, Rogers et al. 2009). Furthermore, effects of development tend to act cumulatively over time (McKinney 2002). Because road and human population densities are highly correlated with housing density in our region (Radeloff et al. 2005, Rogers et al. 2009), we used housing density here to compare tribal and nontribal lands.

We next compared forest structure, biomass, and corresponding levels of carbon storage between the four largest reservations and nearby nontribal lands. For these comparisons, we relied on published sources. Trees accumulate biomass steadily as they grow, meaning that older trees of high diameter contain far greater biomass than younger trees of smaller diameter. Mature forests on sites with a favorable site index support fewer, larger trees but contain more total tree biomass and sequestered carbon (per tree and per unit area) than forests of smaller trees. A stand's basal area reliably predicts these quantities (Slik et al. 2010, Torres and Lovett 2013), allowing surveys of tree diameters like the U.S. Forest Service Forest Inventory and Analysis program to provide reliable estimates of above- and below-ground forest carbon when used in conjunction with MODIS imagery and ancillary geospatial data (Birdsey 1992, Birdsey et al. 1993, https://www. fia.fs.fed.us/forestcarbon/).

We examined patterns of tree regeneration using a variety of sources including historical accounts, long-running Forest Inventory and Analysis (FIA) data collected by the U.S. Forest Service, and field data collected by ourselves and our colleagues in several studies. These included regional variation in tree regeneration (using data from Bradshaw and Waller 2016) and 50 -year shifts in community composition (using data from 
Rooney et al. 2004 and Wiegmann and Waller 2006). These studies did not explicitly compare tribal and nontribal forestlands as we do here. We reanalyzed tree seedling demography data collected by S. Solheim and D. Waller in 1990-1991 from 235 forest sites in northern Wisconsin dominated by eastern hemlock (Tsuga canadensis) or northern white cedar (Thuja occidentalis). Conspicuously low regeneration occurred at most sites (Rooney et al. 2000, 2002). We compared the number of $4-300 \mathrm{~cm}$ tall tree seedlings among five ownerships: the Menominee and Lac du Flambeau Ojibwe reservations; National Forests (ChequamegonNicolet and Ottawa); the Apostle Islands National Lakeshore; and other private and public forestlands. To reduce skew and accommodate the many 0 values, we added 1 to all values and $\log$ transformed the data. We further analyzed tree survival and recruitment using data from a 20-year experiment installed in 1991 by W. S. Alverson and D. M. Waller (unpublished manuscript). In this experiment, arrays of labeled hemlock seedlings were planted in and outside of 59 replicate fenced exclosures distributed among three national forests and two tribal reservations. We then tracked the survival and growth of these seedlings every 3-6 years until 2011 (20 years). We present data on both survival and mean height (including $0 \mathrm{~s}$ ).

White-tailed deer (Odocoileus virginianus, "deer" henceforth) populations respond sensitively to landscape conditions, benefiting from more intensive forest management and plentiful edge habitat (Leopold 1933). They now act as a "keystone herbivore" to strongly influence forest community structure and dynamics (Waller and Alverson 1997). Deer are the dominant vertebrate herbivore in the study region, affecting forest tree regeneration, understory structure, and herbaceous diversity with cascading effects on mammals, birds, and other components of diversity (Fuller 2001, Rooney and Waller 2003, Côté et al. 2004, Waller 2014). We compared estimated deer densities between tribal lands and adjacent DMUs between 2002 and 2013 using Wisconsin Department of Natural Resources (Wisc-DNR) Wildlife Bureau estimates of deer density because these are uniformly estimated and reasonably accurate (Millspaugh et al. 2009, Van Deelen et al. 2010, Wisconsin Department of Natural Resources 2017). Because these estimates extend over countysized areas of land, they likely underestimate actual differences in deer density between the smaller reservations and nontribal lands (e.g., estimates for Lac du Flambeau from DMU 29B are likely biased upwards; J. Gilbert, Great Lakes Indian Fish and Wildlife Commission, personal communication). Because no more recent DNR data exist for Menominee County, we estimated deer density there using the 1990 s figure $\left(3.7 / \mathrm{km}^{2}\right)$.

Further details on our methods, particularly for statistical analyses, appear alongside the results we present below. The differences that emerge from these comparisons raise concerns about whether common nonindigenous management practices can sustain core values like forest and wildlife diversity and longterm forest structure and productivity. We therefore consider in the Discussion what lessons we might draw from indigenous stewardship relevant for improving forest and wildlife management on nontribal lands. This could help them reach the goals declared in forest management guidelines and certification programs (Table 1).

\section{RESULTS}

Forestland type, cover, and landscape conditions

Tribal and nontribal lands in northern Wisconsin support similar forest cover types except that the northern State Forests and Lac du Flambeau reservation support somewhat higher conifer cover (Fig. 2). Tribal and public forestlands also show similar levels of variation in their composition. Although tribal forestlands tend to support more mature forests, they do not differ in type.

Fig. 2. Dominant forest cover types present on tribal lands and nearby federal and state forestlands in northern Wisconsin. Note the similarity in these basic forest types across ownerships. Data from Wiscland 2.0 (http://dnr.wi.gov/maps/ gis/datalandcover.html)

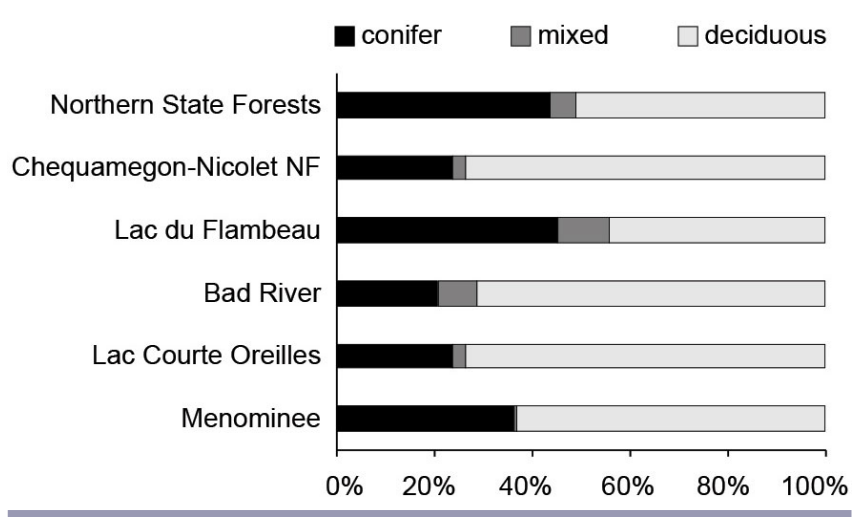

Landscapes vary across northern Wisconsin in forest density, cover type, ownership, and housing density (Figs. 1A and 1B). Differences in landcover are particularly evident along the western edge of the Menominee reservation, a sharp division visible from space (e.g., Google Earth). Housing densities (Fig. 1B) closely parallel road and human population densities and so can be taken as a proxy for these. At $\sim 5$ people per $\mathrm{km}^{2}$, Menominee County is the least populated county in Wisconsin. More than $90 \%$ of it is forested, a figure matched in only two other Wisconsin counties (Perry et al. 2008). The next three largest reservations, in order, have densities of 2.0,5.9, and 10.3 people per $\mathrm{km}^{2}$ (relative to an average of $40.6 / \mathrm{km}^{2}$ statewide). These different landscape conditions and population densities likely contribute to the ecological differences documented below.

\section{Forest biomass/carbon storage}

The map of tree live biomass (Fig. 1A) based on these data from 2009 shows that the Menominee reservation supports as much or more tree biomass as any other large ownership in northern Wisconsin. A half-century ago, this difference was even more pronounced: "except for Menominee Co., there is very little large saw timber found in Wisconsin" (Williams 1967). The fact that the Menominee has supported large trees and a complex forest structure for a long period supports the idea that it has also supported healthy populations of mammal, bird, amphibian, invertebrate, plant, and fungal species that thrive under mature forest conditions throughout this period. Such species include American marten (Martes americana), Pileated Woodpecker (Dryocopus pileatus), and Lobaria lichens (Alverson et al. 1994). 


\section{Deer populations}

Menominee County and the larger Ojibwe reservations have supported lower densities of deer than nontribal lands in northern Wisconsin for many years. Creed and Stearns (1967) reported a density of 1.4 deer per $\mathrm{km}^{2}$ in 1960 in the Menominee reservation relative to 4.6-8.1 in three surrounding deer management units. Menominee's deer density increased to 2.8 in 1965 following the involuntary imposition of state management causing immediate "detrimental effects on vegetation." In the early 1990s, densities were estimated at $\sim 3.7$ per $\mathrm{km}^{2}$.

Tribal lands support consistently lower deer densities than the county-sized DMUs immediately surrounding them (Table 3, Figs. 3 and 4). Estimated fall deer population densities on the Ojibwe reservations averaged 3.1-7 deer per $\mathrm{km}^{2}$ of suitable habitat, 22\%-59\% lower than in surrounding DMUs. Menominee deer densities, in particular, appear to be conspicuously $(72 \%)$ lower than densities in surrounding DMUs. These differences disappear in smaller reservations like Red Cliff, probably reflecting the mobility of deer. These difference in deer density appear related to many of the differences in ecological conditions described next.

Table 3. Comparison of deer densities on and near tribal lands in Wisconsin between 2002 and 2013. Matched nearby areas are the counties surrounding each tribal reservation. Statistics show results of paired t-tests for the 12 yearly values. Areas are in $\mathrm{km}^{2}$ and densities are in deer per $\mathrm{km}^{2}$. Data courtesy of the Wisconsin Department of Natural Resources (2017).

\begin{tabular}{lccccc}
\hline \hline & & \multicolumn{2}{c}{ Mean Densities: } & & \\
\cline { 3 - 4 } $\begin{array}{l}\text { Tribe/ } \\
\text { reservation }\end{array}$ & Area & $\begin{array}{c}\text { On } \\
\text { reservation }\end{array}$ & $\begin{array}{c}\text { Adjacent } \\
\text { DMUs }\end{array}$ & $\begin{array}{c}\text { Mean } \\
\text { difference }\end{array}$ & t-ratio \\
\hline Menominee & 922 & 3.7 & 13.4 & 9.7 & \\
Bad River & 632 & 3.0 & 7.3 & 4.3 & $16.46^{* * * *}$ \\
$\begin{array}{l}\text { Lac Courte } \\
\text { Oreilles }\end{array}$ & 280 & 7.1 & 9.0 & 2.0 & $7.429^{* * *}$ \\
$\begin{array}{l}\text { Lac du } \\
\text { Flambeau }\end{array}$ & 280 & 3.5 & 7.8 & 4.3 & $21.12^{* * *}$ \\
\hline
\end{tabular}

$* * * \mathrm{p}<0.0001$

\section{Invasive species and understory plant diversity}

Resurveys of 62 forest sites in northern Wisconsin show that most sites have declined in native plant diversity since the 1950s (Rooney et al. 2004). In contrast, resurveyed sites in the Lac du Flambeau and Lac Courte Oreilles (Ojibwe) reservations showed slight increases in diversity. Declining plant species include many species highly palatable to deer, e.g., lilies (Wiegmann and Waller 2006). In contrast, increasing species include some ferns, invasive exotics, and several grasses and sedges, all known to resist or tolerate deer herbivory. In U.S. Forest Service FIA surveys, the number of invasive plant species grew from 9 to 17 between 2004 and 2009 and the frequency of plots with $>2$ invasive species grew from $13 \%$ to $21 \%$ (Perry et al. 2012). Ironically, three state parks that banned hunting for decades lost the most plant diversity through the late 20th century $(>50 \%)$. Unhunted sites lost on average $33 \%$ of their initial plant species richness whereas hunted sites lost $10 \%$, further implicating overabundance of deer. "Heavy deer browsing" is given as the most common (41 of 67) "apparent cause of scarcity" for plants listed by the Lac Courte Oreilles as sensitive or in decline, including orchids, rattlesnake fern (Botrychium virginianum), and ginseng (Panax quinquefolius; unpublished data).

Fig. 3. Changes in deer density between 2002 and 2013 on two Ojibwe reservations and surrounding lands. Lower solid lines (circles) show DNR estimated deer densities in the Bad River (a) and Lac du Flambeau (b) reservations. The upper dotted lines (+ symbols) show mean estimated deer densities for the adjacent the Deer Management Units (DMUs). Estimates are based on the sex-age-kill model as implemented by the Wisconsin DNR. a) Bad River

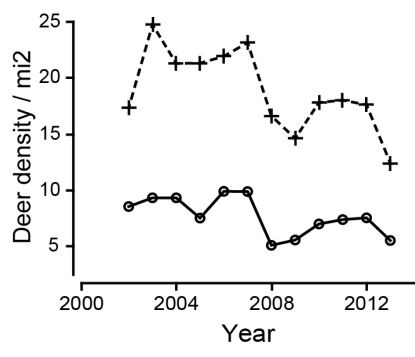

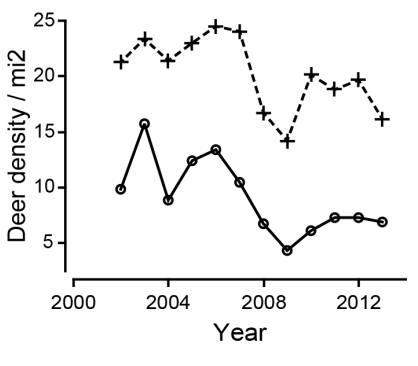

b) Lac du Flambeau

Fig. 4. Trajectories of growth in mean height in eastern hemlock (Tsuga canadensis) seedlings growing in and outside fenced exclosures located in three national forests (a) and two tribal reservations (b). Upper solid lines show mean hemlock heights (square root transformed) inside the exclosures. Seedling growth and survival are restricted by deer browsing far more within the national forests than in the tribal lands. Abbreviations: $\mathrm{CNF}=$ former Chequamegon National Forest; $\mathrm{NNF}=$ former Nicolet NF; ONF = Ottawa NF; LDF and Men = Tribal lands. Note: seedlings on the Men reservation were not tracked after 1997. Source: Alverson, Lea, and Waller, unpublished data.
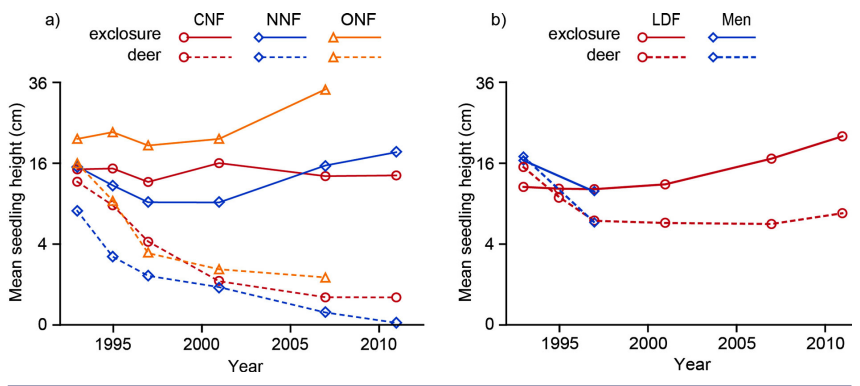

\section{Forest tree regeneration}

Conspicuous differences in rates of tree regeneration on tribal vs. nontribal lands have been noted for years. Swift (1948) documented higher recruitment of several tree species (Quercus, Pinus, Tsuga, Thuja, etc.) on tribal than on nontribal lands more than 60 years ago. This distinction continues. Reo and Karl (2010) compared browsing rates and seedling numbers of northern red oak (Quercus rubra) between Ojibwe and nearby state forestlands and found large differences. Reservations experience half as much browsing, allowing 1.5 to $4 \mathrm{x}$ as many seedlings to survive. In 
reviewing forest conditions on ceded (off-reservation) Ojibwe Territories in Wisconsin, Michigan, and Minnesota, Kurtz et al. (2015) noted that aspen ( P. tremuloides and $P$. grandidentata) have become dominant on $20 \%$ of timberlands, that sugar maple has increased since 1980, and that northern white-cedar was aging with few small diameter trees.

Using data collected by S. Solheim and D. Waller in 1990-1991 from 235 hemlock and cedar forest stands in northern Wisconsin, we analyzed separately the number of hemlock, cedar, and all tree seedlings in two-way analyses of variance. Ownership and forest type (hemlock vs. cedar) are treated as fixed factors. Tribal lands support higher densities of cedar and hemlock seedlings than nontribal lands (Table 4, Fig. 5). Back-transformed data from the adjusted means reveal that the Lac du Flambeau tribal lands had $1.02 \mathrm{x}$ more tree seedlings, $1.26 \mathrm{x}$ more hemlock seedlings, and $3.47 \mathrm{x}$ as many cedar seedlings as the national forests. Menominee lands had $1.40 \mathrm{x}, 5.65 \mathrm{x}$, and $2.05 \mathrm{x}$ as many, respectively. These higher rates of recruitment, accentuated in the most preferred species, the most reflect lower deer densities and/or better seedbed conditions (rotting logs, cool, moist microsites, etc.) on tribal forestlands (Rooney and Waller 1998). These higher rates of recruitment, accentuated in the deer-preferred species, strongly support the idea that lower deer densities on tribal lands promote healthy forest regeneration. The generally more mature tribal forests also tend to support better seedbed conditions, e.g., rotting logs and cool, moist microsites, which may further enhance regeneration (Rooney and Waller 1998). Across northern Wisconsin, distributions in the number of 2.5-5.1 cm saplings are extremely skewed with a major mode of 0 in five species favored by deer (Tsuga, Thuja, Betula alleghaniensis, Pinus strobus, and Quercus rubra; Bradshaw and Waller 2016). Seedling numbers are less skewed on tribal lands (analyses not shown). Table 5 compares sapling numbers among ownerships in B. alleghaniensis. Conspicuously higher recruitment occurs on the larger reservations.

Table 4. Results from analyzing variation in tree seedling numbers among 235 sites distributed among five ownership classes: the Menominee and Lac du Flambeau reservations, National Forests (Chequamegon, Nicolet, and Ottawa), the Apostle Islands National Lakeshore, and other private and public forestland (Solheim and Waller, unpublished data). Summary of results from two-way ANOVA's of the (log) numbers of seedlings for all tree species, eastern hemlock (Tsuga canadensis), and northern white cedar (Thuja occidentalis). Differences among ownerships shown in Figure 7.

\begin{tabular}{|c|c|c|c|c|c|c|c|}
\hline \multirow[b]{2}{*}{ Source } & \multirow[b]{2}{*}{$\mathrm{DF}$} & \multicolumn{6}{|c|}{ F Ratios: ANOVA's of Log (\#Seedlings + 1) for: } \\
\hline & & all trees & & Hemlock & & Cedar & \\
\hline Ownership & 4 & 1.6857 & & 9.477 & $\begin{array}{l}*_{-} \\
* *\end{array}$ & 4.2343 & $* *$ \\
\hline Forest Type & 1 & 1.4293 & & 5.5759 & $*$ & 165.5129 & $* * *$ \\
\hline $\begin{array}{l}\text { Type } \mathrm{x} \\
\text { Owner }\end{array}$ & 4 & 5.9879 & $\begin{array}{l}*_{-} \\
* *\end{array}$ & 6.757 & $\begin{array}{l}*_{-} \\
* *\end{array}$ & 8.0102 & $* * *$ \\
\hline
\end{tabular}

The 20-year experiment tracking hemlock seedling in and outside 59 fenced exclosures further confirms that tribal lands support higher growth and survival of hemlock seedlings than nontribal land and that deer account for most of these differences. Most unprotected hemlock seedlings survived to grow taller on tribal lands whereas most seedlings died in the nearby national forests (relative survival: $60.3 \%$ in Lac du Flambeau vs. $21.4 \%$ and $4.3 \%$ in the Chequamegon and Nicolet NFs, respectively). Similarly, the ratio of average seedling heights in vs. outside the exclosures (including zeros) grew from 1.41 in 1993 to 2.6, then 12.2, and finally to $>1000$ in the national forests (by 1995, 2001, and 2011, respectively; Fig. 4). In contrast, these recruitment ratios grew from 0.87 to 2.87 over this interval on tribal lands, reflecting healthy regeneration.

Fig. 5. Differences in mean tree seedling numbers found at 235 sites distributed among five ownership classes in northern Wisconsin in 1991-92 (Solheim and Waller, unpublished data). Graph shows adjusted least square mean values ( \pm S.E.) for $\log$ seedling numbers of hemlock, cedar, and all tree seedlings per $98 \mathrm{~m}^{2}$ computed from two-way ANOVA's with ownership and forest type (cedar vs. hemlock) as factors (ANOVA results in Table 4). Ownership abbreviations: API = Apostle Islands National Park; LDF = Lac du Flambeau reservation; MEN = Menominee reservation; Natl Forest $=$ the Chequamegon, Nicolet, and Ottawa National Forests; and ELSE = all other ownerships.

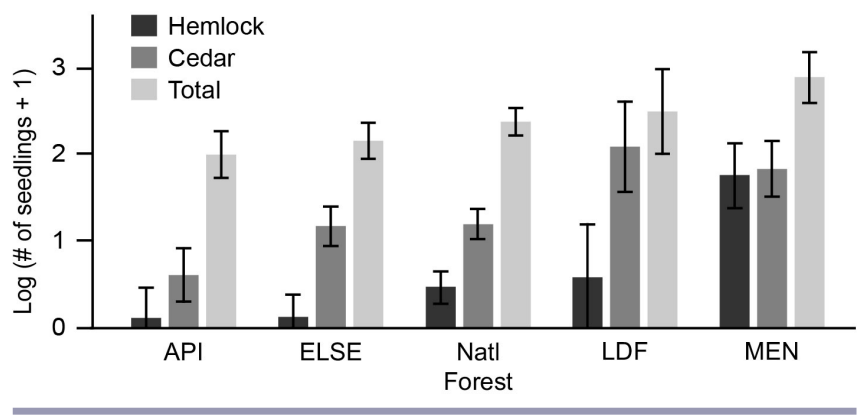

Both historical and contemporary studies thus confirm that tribal lands support greater tree regeneration, not only for slow-growing late-successional conifers like cedar and hemlock but also hardwoods like red oak and yellow birch. Successful regeneration across a range of taxa helps maintain species diversity and structural diversity of forests, important factors for wildlife habitat. Oaks provide acorn mast while hemlock and cedar stands provide key habitats for deer that provide forage and thermal cover in "deer yards" during severe winters.

\section{DISCUSSION}

Indigenous Nations in Wisconsin have long managed their lands, waters, and wildlife in ways that reflect their cultural traditions and values. Their practices differ from those applied on other public and private forestlands in the region. Here, we asked whether these differences have altered ecological conditions on tribal lands relative to nontribal lands. We compared conditions on the Menominee and larger Ojibwe reservations to those on nearby public forests (or forestlands in general) in northern Wisconsin. After confirming that forest types do not differ greatly 
between tribal and nontribal owners, and thus that other results do not reflect artifacts (Fig. 2), we found evidence for differences in most remaining conditions (Table 6). We found that forest structure, biomass, and sequestered carbon on the Menominee reservation to be as great or greater as other forestlands in Wisconsin (Fig. 1A), which also shows the lowest housing density of any county in the state (Fig. 1B). The Menominee forests sustain more standing timber and thus carbon than most other forests in the region and have done so for the past century. Oldgrowth forests continue to fix and store carbon for centuries, outperforming younger forests in both respects (Luyssaert et al. 2008). The remaining four comparisons all showed marked and statistically significant quantitative differences. Menominee and the largest Ojibwe forests also sustain greater biodiversity and higher tree regeneration than nontribal lands. In contrast, deer are less abundant on tribal lands, accounting at least partly for the higher diversity and regeneration success seen there.

Table 5. Results of general linear model analyzing variation in regeneration success ( $\log$ of $1+$ the number of tree saplings 2.6$5.1 \mathrm{~cm} \mathrm{DBH})$ of Betula alleghaniensis among five tribal reservations and nontribal lands in northern Wisconsin between 1983 and 2011. Data derived from all U.S. Forest Service Forest Inventory and Analysis (FIA) survey sites in northern Wisconsin. "Overstory density" refers to the average number of large $B$. alleghaniensis trees ( $>\mathrm{cm}$ DBH) at those sites while "basal area" refers to the average total basal area of the stand (an estimate of overall canopy density). Regeneration success on the Lac Courtes des Orielles $(0.01 \pm 0.076)$ and Bad River $(0.043 \pm 0.076)$ reservations was low, similar to the small numbers of saplings found on nontribal lands (mean $0.036 \pm 0.013)$, but regeneration was higher on the Menominee (0.296 \pm 0.079$)$, Red Cliff $(0.139$ $\pm 0.075)$, and Lac du Flambeau $(0.114 \pm 0.082)$ reservations. Values are least-squares means $( \pm$ S.E. $)$, adjusted for other factors and covariates. Overall $\mathrm{r} 2=0.37$.

\begin{tabular}{|c|c|c|c|c|}
\hline Source & $\mathrm{DF}$ & Sum of Squares & F Ratio & Prob $>$ F \\
\hline Overstory Density & 1 & 0.0442 & 7.77 & $0.006^{*}$ \\
\hline Basal Area & 1 & 0.1254 & 22.06 & $<0.0001 *$ \\
\hline Ownership & 5 & 0.0685 & 2.41 & $0.039 *$ \\
\hline Decade & 3 & 0.0640 & 3.75 & $0.012 *$ \\
\hline Ownership x Decade & 15 & 0.2041 & 2.39 & $0.004 *$ \\
\hline
\end{tabular}

What factors drive these conspicuous differences in biological conditions? Land and forest management likely account directly for differences in landscape conditions and standing volume on tribal forestlands. Tribal lands are less developed, with fewer people, roads, and houses than most private ownerships. The Menominee have managed most of their forests using long rotations and selective logging that favor structural diversity and large diameter trees since before 1865 (Trosper 2007). Yazzie (2007) notes that in the U.S., broadly speaking, tribal decisions to manage forests for old growth characteristics are fundamentally tied to beliefs about direct linkages between healthy forests and the health and welfare of Native peoples.

Outcomes from these differences in management are conspicuous (Figs. 3, 4, 5). Tribal lands retain higher understory plant diversity over the past half-century while other ownerships (particularly state parks) have lost diversity (Rooney et al. 2004). This probably stems primarily from differences in deer management, though it may also reflect differences in soil, light, and humidity found in mature forests and the abundance of "nurse" logs and other coarse woody debris. Such conditions provide microsites for species sensitive to light and drought including many ferns, orchids, and tree seedlings.

These plant diversity results align with findings on indigenous lands outside of our study region. Indigenous land managers use a variety of practices to promote biodiversity across space, e.g., managing for landscape patchiness, and time, e.g., succession management, to create a steady supply of wild foods and medicines (Berkes and Davidson-Hunt 2006, Sayles and Mulrennan 2010, Lepofsky et al. 2017) and because indigenous societies commonly recognize tight linkages between ecosystem health and human health (Parlee et al. 2005a). For instance, agroforestry practices are used by various indigenous peoples to restore soil productivity and generate diverse assemblages of trees and shrubs (Marquardt et al. 2013, Warren and Pinkston 1998).

A key factor accounting for many of the differences we found is the differential abundance of white-tailed deer. Tribes in Wisconsin manage deer assertively, reducing their density relative to nontribal lands. In contrast, the State of Wisconsin manages deer primarily for the recreational value of deer hunting. Impacts to other resources are of secondary importance. These recreational values of deer include the opportunity to readily harvest deer (especially large bucks), seeing many deer while hunting, and backyard viewing and feeding (K. McCaffery, personal communication). Until 2010, additional antlerless permits and supplemental antlerless seasons were used to control herd sizes (Willging 2008). If this failed and deer numbers continued to increase, an "Earn-a-buck" system kicked in that required hunters to shoot a doe before being able to shoot bucks. This was so unpopular that hunters mobilized to defeat it. The unwillingness of many hunters to shoot does, venture far from roads, or shoot multiple animals limited the Wisc-DNR's ability to use hunting to contain the herd. To respond to political pressures over deer management, Gov. S. Walker commissioned an external review of Wisconsin deer management resulting in a Deer Trustee Report (Kroll et al. 2012). This delegated responsibility for managing deer numbers to the county level and involved hunters directly in management. These actions have further reduced the discretion and ability of agency deer managers to limit herd sizes in Wisconsin.

Lower densities on tribal lands allow understory plants, including tree seedlings and saplings, shrubs, and herbaceous plant species to thrive. Deer in our region are known to strongly affect understory plant cover and diversity, community composition, rates of nitrogen cycling, and tree regeneration (Côté et al. 2004, Rooney and Waller 1998, 2003, Rooney et al. 2000, 2002, Waller 2014, Bradshaw and Waller 2016). Thus, high deer densities are likely responsible for many of the long-term shifts in community composition observed here (Frerker et al. 2014). We observed the biggest declines in tree regeneration in Tsuga and Thuja, species known to be favored by deer and sensitive to browsing. However, they also extend to hardwoods like northern red oak and yellow birch (Betula alleghaniensis), which continue to regenerate poorly in Wisconsin (Bradshaw and Waller 2016). High deer densities may also account for regional declines in the abundance of 
Table 6. Summary of the differences found between conditions on tribal and nontribal lands in Wisconsin and their known or likely ecological consequences.

\begin{tabular}{|c|c|c|}
\hline Condition & How reservations compare & Known or likely consequences \\
\hline Forest type and composition & $\begin{array}{l}\text { Similar in forest type and overall composition } \\
\text { (Fig. 2). }\end{array}$ & $\begin{array}{l}\text { Differences in other conditions here are not likely } \\
\text { to reflect systematic differences in forest type. }\end{array}$ \\
\hline $\begin{array}{l}\text { Landscape conditions (human population, } \\
\text { housing and road density) }\end{array}$ & $\begin{array}{l}\text { Lower housing density (Fig. 1B), highly } \\
\text { correlated with population and road density. }\end{array}$ & $\begin{array}{l}\text { Fewer human-wildlife conflicts; more habitat for } \\
\text { sensitive species. }\end{array}$ \\
\hline Forest structure and biomass/carbon. & $\begin{array}{l}\text { Higher tree volume for the last } 150+\text { years in the } \\
\text { Menominee reservation (Fig. 1B) }\end{array}$ & $\begin{array}{l}\text { Higher carbon storage; better habitat for species } \\
\text { that depend on late seral conditions. }\end{array}$ \\
\hline White-tailed deer densities & $\begin{array}{l}28 \% \text { to } 78 \% \text { relative to surrounding DMUs with } \\
\text { larger reservations having greater difference } \\
\text { (Table } 3 \text {, Fig. } 3 \text { ) }\end{array}$ & $\begin{array}{l}\text { Higher tree regeneration and a greater diversity } \\
\text { of species; denser and more diverse forest } \\
\text { understories; more conifer stands for winter } \\
\text { deeryards; more and higher quality deer forage. }\end{array}$ \\
\hline $\begin{array}{l}\text { Forest understory diversity and changes in } \\
\text { diversity }\end{array}$ & $\begin{array}{l}\text { No net loss in forest plant diversity over } 50+ \\
\text { years vs. mean loss of } 15-20 \% \text { elsewhere and } \\
50 \% \text { losses in WI state parks (Rooney et al. 2004) }\end{array}$ & $\begin{array}{l}\text { Denser, more diverse understories better support } \\
\text { overall biodiversity. }\end{array}$ \\
\hline Regional patterns of tree regeneration & $\begin{array}{l}\text { Higher rates of regeneration for many tree } \\
\text { species including Thuja occidentalis, Quercus } \\
\text { rubra, Pinus strobus, and Betula alleghaniensis } \\
\text { (Tables } 4 \text { and 5, Fig. 5) }\end{array}$ & $\begin{array}{l}\text { Denser under- and midstory conditions support } \\
\text { more birds that forage or nest in the midstory or } \\
\text { near the ground. Higher rates of regeneration } \\
\text { sustain forest canopy diversity, valuable timber } \\
\text { species, and greater resilience to stresses like } \\
\text { climatic warming. }\end{array}$ \\
\hline $\begin{array}{l}\text { Survival and growth of Tsuga canadensis } \\
\text { seedlings for } 15-20 \text { years }\end{array}$ & $\begin{array}{l}3-15 x \text { greater survival on tribal lands; } 12-9000 x \\
\text { greater growth (Fig. } 4 \text { ) }\end{array}$ & $\begin{array}{l}\text { Diminishing hemlock abundance and the loss of } \\
\text { key habitats for deer and other species. }\end{array}$ \\
\hline
\end{tabular}

songbirds that forage or nest in forest understories (McShea and Rappole 2000, Allombert et al. 2005, Chollet and Martin 2013).

Low deer densities on tribal lands emerge from flexible hunting policies focused on cultural values. Within the Lac du Flambeau Nation, tribal laws set no hunting seasons or bag limits for its citizens (Reo and Whyte 2012). Informal deer hunting rules on the Tribe's reservation are enforced socially, not by wardens. Ojibwe hunters seek venison to support community needs, not individual interests. Cultural and community orientations of hunting are common for indigenous peoples beyond our study area (McCorquodale 1997). The cultural and social foundations of indigenous communal hunting institutions are well documented in other regions (Berkes 1998, Parlee et al. 2005b, Sayles and Mulrennan 2010); additional work on this topic within the Great Lakes would help sort out important humanenvironment linkages in Wisconsin forestlands.

Wolf (Canis lupus) populations represent another potentially relevant factor that could be playing an important role in the outcomes documented here. The Ojibwe, in particular, revere and respect wolves (ma'iingan), considering them to be their brothers whose fate is tied directly to that of their Indigenous Nation (David 2009, Usik 2015). Ojibwe hunters view ma'iingan not as competitors but rather as family members who, like people, need to eat. To reinforce this kinship, they share their deer with wolves, eagles, and bears by leaving ceremonial offerings and unused portions of animals in the woods (Reo and Whyte 2012). No Indigenous Nation in Wisconsin approves the sport hunting or trapping of wolves, practices pursued eagerly elsewhere in northern Wisconsin. Hunters and trappers killed 374 wolves so efficiently between 2012 and 2014 that they forced early ends to the wolf season. In 2012, the Voigt Intertribal Task Force passed a motion that unanimously opposed the killing of ma'iingan, arguing that all wolves in the ceded territories are needed to sustain a state-wide population sufficient to preserve Ojibwe rights. By contrast, many nonindigenous people in the region openly express animosity toward wolves (Fig. 6). Antiwolf feelings persisted even after wolf hunting and trapping were implemented in Wisconsin (Treves and Bruskotter 2014).

Fig. 6. Photos exemplifying contrasting views regarding wolves in the Great Lakes region by (A) Indigenous Nations such as the Fond du Lac Band of Lake Superior Chippewa Indians and (B) a segment of settler Americans.

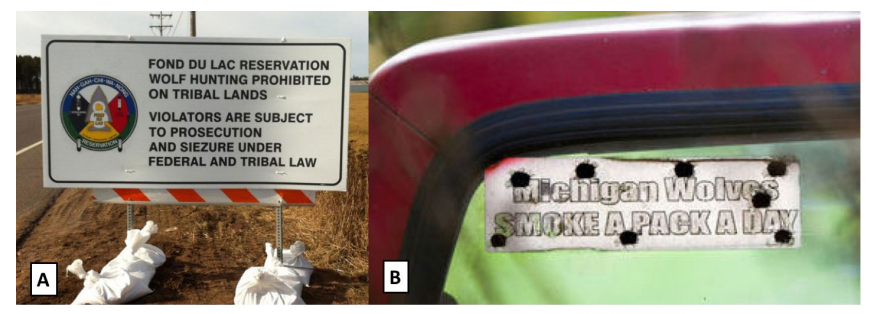

These differences in perspective and behavior makes it likely that tribal lands support wolf populations as high or higher than surrounding forestlands and packs that experience more social stability and fewer disruptions. Wolves act as apex predators to affect the population densities and behavior of ungulates, mesopredators, and many other species (Crête and Manseau 1996, Crête 1999, Ripple and Beschta 2005). Such cascading effects are being documented in our region (Callan et al. 2013, Flagel et al. 2016). Because we lacked fine-scale data on wolf populations, we could not quantify any difference that may exist in wolf densities or effects. 


\section{Lessons for public lands management}

State and national forests in Wisconsin embrace ecosystem management and its emphasis on protecting soils, wildlife populations, and ecological conditions (Table 1). Sustainability standards for the Forest Stewardship Council (FSC, https://us. fsc.org/en-us) and Sustainable Forestry Initiative ${ }^{\circledR}$ (SFI, http:// www.sfiprogram.org/) promote similar goals. Standards for certification seek to protect biological diversity (SFI "Forest Productivity and Health Principle 1") and apply management to sustain diversity and "provide for regeneration after harvest" (Principle 2). The 2004 U.S. Forest Service Land and Resources Management Plan for the Chequamegon-Nicolet National Forest states its first goal to be: "Ensure Healthy and Sustainable Ecosystems..." and to do so, "in healthy, diverse, and productive conditions that support the diversity of plant and animal communities and tree species" (Goal 1.4) while protecting "desired conifer regeneration from deer browsing" (Goal 1.4f). These goals emerged from the 1976 National Forest Management Act and associated federal regulations requiring the USFS to sustain biological diversity and forest productivity (Alverson et al. 1994). Management plans for SFI-certified Wisconsin State Forests state similar goals, e.g., "Manage the forest and its resources using principles of ecosystem management and sustainable forestry consistent with the ecological capability of the land" and "Identify and protect rare, threatened and endangered species" (goals 1 and 2, 2007 Master Plan, Pestigo State Forest).

Despite these stated goals regarding ecological conditions and values, many common forest tree species are failing to regenerate across northern Wisconsin and have failed to do so for decades (Bradshaw and Waller 2016). These failures and our observations of long-term declines in native plant diversity suggest that public forestlands in northern Wisconsin fall short of meeting their stated objectives and external certification standards. State and federal forestland managers rarely monitor forest ecological conditions beyond the USDA Forest Service FIA surveys (Alverson et al. 1994, Waller 2008). These only provide accurate data for tree saplings $>2.5 \mathrm{~cm} \mathrm{DBH}$ and so represent a lagging indicator. Without more detailed and accurate monitoring, it is difficult to know whether ecological targets published in planning documents and certification standards are being met. Furthermore, the limited data available from USDA's FIA program are rarely used to shape decisions. This falls short of the potential agencies have to incorporate contemporary monitoring data into a meaningful adaptive management cycle. Federal and state agencies do track populations of threatened and endangered species (including wolves currently) but they do not track the cascading effects of predators on ungulates and other ecosystem processes (Alverson et al. 1994). In sum, public forest managers are neither tracking key ecological indicators nor using the data that are available to adjust management or assess the sustainability of their management practices. These shortcomings in monitoring and adaptive management reflect many factors including a lack of funding for monitoring, few enforced standards or guidelines on adaptive management, and how hard it is to connect ecological outcomes to particular drivers (Waller 2008). Better monitoring of ecological conditions with clear criteria and guidelines for sustainability would enhance the ability of Wisconsin forests to meet their stated goals.
How can land managers address the impacts of high deer densities? They might first seek to enhance hunting opportunities and promote tolerance toward large predators, enlisting the support of both wildlife biologists and social scientists. Wildlife managers could also actively recruit hunters motivated primarily to hunt for food (more like tribal hunters). Wisconsin has experimented with targeted learn-to-hunt-for-food programs in urban areas in southern Wisconsin. Outreach and hunter training courses could also be extended to include information on forest ecology, the ecological impacts of overabundant deer, and the roles than humans and wild predators play in regulating deer populations. Finally, hunters and other "citizen scientists" could be mobilized to measure local deer habitat conditions and forest conditions, generating timely data for wildlife managers. Sharing data on deer impacts might also help shift attitudes toward predators and desired deer densities. More, and more timely, data plus broader public support could enable forest and wildlife managers to pursue practices more in line with their stated goals and sustainability standards.

\section{CONCLUSIONS}

We conclude that Wisconsin's tribal Nations steward forests in ways that foster sustainability. These outcomes reflect in part the fact that these Nations see their health and welfare tied directly to the health of their forests. This connection is well documented for the Menominee Nation, where the inseparability of human and forest health lies at the heart of how they manage their forests (Pecore 1992, Davis 2000). Menominee forests were among the first to be certified as sustainable, providing a model of success that attracts visitors from around the world. Their forestlands exceed nontribal lands in measures of ecological function (biomass, carbon storage, and plant diversity) and the criteria commonly used to assess forest sustainability (sustained yields, forest stature, and diversity, natural regeneration success). Furthermore, they have done so for more than a century, demonstrating cultural resilience despite strong historical pressures to alter their management.

Indigenous Nations in Wisconsin have managed their forestlands and wildlife in ways that benefit the ecosystems they oversee, their own people, and other citizens. State and federal agencies have opportunities to learn from tribal experiences as they seek to achieve their stated goals and reach sustainability standards. Our paper provides a scientific rationale for public land and wildlife managers in Wisconsin to benefit from the experience and success of Indigenous Nations, the first stewards of Wisconsin forests. We do not prescribe any single best way to steward forests and wildlife, nor do we promote any particular knowledge system here. Rather, we feel that being open to continual learning and alternative ways of understanding the world provide a better basis for stewarding resources in an era experiencing rapid environmental change (Berkes 2004, Chapin et al. 2009, 2011). Being open to learning is vital if we are to effectively address pressing issues like deer overabundance and how to steward forests to maximize resilience in the face of changing climatic conditions and novel pests and pathogens. The diverse perspectives of indigenous peoples, in northern Wisconsin and around the world, enhance their ability to contribute meaningfully to natural resource policy and management. 
Policy in the U.S. dictates that public land managers coordinate natural resource management with Indigenous Nations. Supreme Court rulings including the 1999 Minnesota v. Mille Lacs Band of Chippewa Indians case concerning off-reservation treaty rights in Minnesota (526 U.S. 172) have served to formalize cooperative stewardship regimes between tribal, state, and federal governments. Federal laws and regulations require consultation with tribes, including National Historic Preservation Act (16 U. S.C. 470 et seq.), Native American Graves Protection and Repatriation Act (25 U.S.C. 3001, et. seq.), and the National Environmental Policy Act. Executive orders and formal memoranda (e.g., E.O. 13175 of 2000 concerning "Consultation and Coordination with Indian Tribal Governments") signal that federal land managers "are charged with engaging in regular and meaningful consultation and collaboration with tribal officials in the development of Federal policies that have tribal implications, and are responsible for strengthening the government-togovernment relationship between the United States and Indian tribes, (Pres. Obama's Memorandum on Tribal Consultation, 5 November 2009). These policies have led to agency-specific actions including the USDA's "Action Plan for Tribal Consultation and Collaboration" and Forest Service Planning Rule (Section 219.4), which requires the agency to engage tribes in national forest planning including "information about native knowledge, land ethics, cultural issues, and sacred and culturally significant sites."

To date, comanagement in the ceded territories of the upper Great Lakes region has focused on discrete fish and wildlife populations. However, the tribal ecosystem management successes reported in this paper, coupled with federal policies that call for broad cooperation with tribal Nations, indicate that broader comanagement arrangements may be warranted and could further benefit both ecological conditions and social welfare. Similar transformations toward holistic, landscape-scale comanagement institutions have been called for in the realm of protected areas management globally (Stevens 2014).

State, tribal, and federal partners have made great progress over the past 25 years in building working relationships based in trust and educating the public about treaty rights in the ceded territories (Busiahn and Gilbert 2011). As these relationships evolve, it may be possible to merge indigenous understandings about land, water, and wildlife more fully into comanagement. Our findings suggest that involving indigenous values, knowledge, and practices in the stewardship of broader landscapes in Wisconsin could increase ecological functionality and promote sustainable resource use. Indigenous understandings, values, and practices are in many ways congruent with Western science-based ecological principles and public land management goals, particularly in the realm of ecosystem management (Berkes et al. 1998, Houde 2007, Busiahn and Gilbert 2011). Both tribal and public land managers seek to sustain healthy ecological conditions and processes on these lands. Shared goals and an openness to both Western scientific and indigenous approaches could lay the foundation for sustainably comanaging shared resources across the ceded territories in the future.

Responses to this article can be read online at: http://www.ecologyandsociety.org/issues/responses. php/9865

\section{Acknowledgments:}

We thank our scientific forebears (J. T. Curtis and students) for collecting and archiving baseline data. We thank the U.S. Forest Service FIA program (C. Barnett and E. LaPoint) for assistance in accessing and using the FIA data. R. Rolley (Wisc-DNR) and T. Van Deelen helped us obtain and interpret deer population data. We are deeply grateful to the Menominee Nation, Lac du Flambeau Tribe of Lake Superior Chippewa Indians and Great Lakes Indian Fish and Wildlife Commission for providing access to data and field sites. J. Schwartzman, M. Waller, and anonymous reviewers provided useful comments on earlier versions of the paper. DMW is grateful to the LABex program and the ISEM group at the Université de Montpellier, France for hosting writing time. NSF (DEB-0717315 and DEB-DoB 1046355) supported the long-term resurvey work.

\section{LITERATURE CITED}

Allombert, S., A. J. Gaston, and J-L Martin. 2005. A natural experiment on the impact of overabundant deer on songbird populations. Biological Conservation 126:1-13. http://dx.doi. org/10.1016/j.biocon.2005.04.001

Alverson, W. S., W. Kuhlmann, and D. M. Waller. 1994. Wild forests: conservation biology and public policy. Island Press, Washington, D.C., USA.

Arcese, P., R. Schuster, L. Campbell, A. Barber, and T. G. Martin. 2014. Deer density and plant palatability predict shrub cover, richness, diversity and aboriginal food value in a North American archipelago. Diversity and Distributions 20(12):1368-1378. http:// dx.doi.org/10.1111/ddi.12241

Bengston, D. N. 2004. Listening to neglected voices: American Indian perspectives on natural resource management. Journal of Forestry. 102(1):48-52.

Berkes, F. 1998. Indigenous knowledge and resource management systems in the Canadian subarctic. Pages 98-128 in F. Berkes and C. Folke, editors. Linking social and ecological systems: management practices and social mechanisms for building resilience. Cambridge University Press, Cambridge, UK.

Berkes F. 2004. Rethinking community-based conservation. Conservation Biology 18(3):621-630. http://dx.doi.org/10.1111/ j.1523-1739.2004.00077.x

Berkes, F., and I. J. Davidson-Hunt. 2006. Biodiversity, traditional management systems, and cultural landscapes: examples from the boreal forest of Canada. International Social Science Journal 58 (187):35-47. http://dx.doi.org/10.1111/j.1468-2451.2006.00605.x

Berkes F., M. Kislalioglu, C. Folke, and M. Gadgil. 1998. Minireviews: exploring the basic ecological unit: ecosystem-like concepts in traditional societies. Ecosystems 1(5):409-415. http:// dx.doi.org/10.1007/s100219900034

Birdsey, R. A. 1992. Changes in forest carbon storage from increasing forest area and timber growth. Pages 23-39 in R. N. Sampson and D. Hair, editors. Forests and global change. Vol. 1: opportunities for increasing forest cover. American Forests, Washington, D.C., USA. 
Birdsey, R. A., A. J. Plantinga, and L. S. Heath. 1993. Past and prospective carbon storage in United States forests. Forest Ecology and Management 58:33-34. http://dx.doi.org/10.1016/0378-1127 (93)90129-B

Bradshaw, L., and D. M. Waller. 2016. Long-term impacts of white-tailed deer on regional patterns of forest tree recruitment. Forest Ecology and Management 375:1-11. http://dx.doi. org/10.1016/j.foreco.2016.05.019

Brandt, J. S., E. M. Wood, A. M. Pidgeon, L. X. Han, Z. Fang, and V. C. Radeloff. 2013. Sacred forests are keystone structures for forest bird conservation in southwest China's Himalayan Mountains. Biological Conservation 166:34-42. http://dx.doi. org/10.1016/j.biocon.2013.06.014

Busiahn, T., and J. Gilbert. 2011. The role of Ojibwe Tribes in the co-management of natural resources in the Upper Great Lakes region: a success story. Pages 152-160 in L. A. McRoy and H. J. Bichler, editors. Minwaajimo: telling a good story: preserving treaty rights for the past 25 years. Great Lakes Indian Fish and Wildlife Commission, Odanah, Wisconsin, USA.

Callan, R., N. P. Nibbelink, T. P. Rooney, J. E. Wiedenhoeft, and A. P. Wydeven. 2013. Recolonizing wolves trigger a trophic cascade in Wisconsin (USA). Journal of Ecology 101:837-845. http://dx.doi.org/10.1111/1365-2745.12095

Carroll, C. 2015. Roots of our renewal: ethnobotany and Cherokee environmental governance. University of Minnesota Press, Minneapolis, Minnesota, USA. http://dx.doi.org/10.5749/ minnesota/9780816690893.001.0001

Ceddia, M. G., U. Gunter, and A. Corriveau-Bourque. 2015. Land tenure and agricultural expansion in Latin America: the role of indigenous peoples' and local communities' forest rights. Global Environmental Change 35:316-322. http://dx.doi.org/10.1016/j. gloenvcha.2015.09.010

Chapin III, F. S., G. P. Kofinas, and C. Folke, editors. 2009. Principles of ecosystem stewardship: resilience-based natural resource management in a changing world. Springer, New York, New York, USA.

Chapin III, F. S., M. E. Power, S. T. A. Pickett, A. Freitag, J. A. Reynolds, R. B. Jackson, D. M. Lodge, C. Duke, S. L. Collins, A. G. Power, and A. Bartuska. 2011. Earth stewardship: science for action to sustain the human-earth system. Ecosphere 2(8):1-20. http://dx.doi.org/10.1890/ES11-00166.1

Chollet, S., and J. L. Martin. 2013. Declining woodland birds in North America: Should we blame Bambi? Diversity and Distributions 19(4):481-483. http://dx.doi.org/10.1111/ddi.12003

Côté, S. D., T. P. Rooney, J.-P. Tremblay, C. Dussault, and D. M. Waller. 2004. Ecological impacts of deer overabundance. Annual Review of Ecology, Evolution, and Systematics 35:113-147. http:// dx.doi.org/10.1146/annurev.ecolsys.35.021103.105725

Creed, W. A., and F. Stearns. 1967. Soil resources and forest ecology of Menominee County, Wisconsin. Wisconsin Geological and Natural History Survey, Madison, WI, Bulletin 85, Soil Series No. 60.

Crête, M. 1999. The distribution of deer biomass in North America supports the hypothesis of exploitation ecosystems.
Ecology Letters 2:223-227. http://dx.doi.org/10.1046/ j.1461-0248.1999.00076.x

Crête, M., and M. Manseau. 1996. Natural regulation of cervidae along a $1000 \mathrm{~km}$ latitudinal gradient: change in trophic dominance. Evolutionary Ecology 10:51-62. http://dx.doi. org/10.1007/BF01239346

David, P. 2009. Ma'iingan and the Ojibwe. Pages 267-277 in A. P. Wydeven, T. R. Van Deelen, and E. Heske, editors. Recovery of gray wolves in the Great Lakes Region of the United States. Springer, New York, New York, USA. http://dx.doi. org/10.1007/978-0-387-85952-1_17

Davis T. 2000. Sustaining the forest, the people, and the spirit. State University of New York Press, Albany, New York, USA.

Dockry, M. J. 2012. Indigenous forestry in the Americas: comparative environmental histories in Bolivia and Wisconsin. Dissertation, University of Wisconsin Madison, Wisconsin, USA.

Flagel, D. G., G. E. Belovsky, and D. E. Beyer Jr. 2016. Natural and experimental tests of trophic cascades: gray wolves and whitetailed deer in a Great Lakes forest. Oecologia 180:1183-1194. http://dx.doi.org/10.1007/s00442-015-3515-z

Forest Inventory Data. 2015. Online web-application version: FIDO 1.5.1.05b. U.S. Department of Agriculture, Forest Service, Northern Research Station, St. Paul, Minnesota, USA. [online] URL: http://apps.fs.fed.us/fia/fido/customrpt/app.html

Forman, R. T. T., and L. E. Alexander. 1998. Roads and their major ecological effects. Annual Review of Ecology and Systematics 29:207-231. http://dx.doi.org/10.1146/annurev. ecolsys.29.1.207

Frerker, K. L., A. Sabo, and D. M. Waller. 2014. Long-term regional shifts in plant community composition are largely explained by local deer impact experiments. PLOS ONE 9(12): e115843. http://dx.doi.org/10.1371/journal.pone.0115843

Fuller, R. J. 2001. Responses of woodland birds to increasing numbers of deer: a review of evidence and mechanisms. Forestry 74:289-298. http://dx.doi.org/10.1093/forestry/74.3.289

Gedicks, A. 1993. The new resource wars. South End Press, Boston, Massachusetts, USA.

Gordon, J., J. Sessions, J. Bailey, D. Cleaves, V. Corrao, A. Leighton, L. Mason, and M. Rasmussen. 2013. Assessment of Indian forests and forest management in the United States. A report by the Indian Forest Management Assessment Team. Intertribal Timber Council. Portland, Oregon, USA.

Hammer, R. B., S. I. Stewart, R. L. Winkler, V. C. Radeloff, and P. R. Voss. 2004. Characterizing spatial and temporal residential density patterns from 1940-1990 across the north central United States. Landscape and Urban Planning 69:183-199. http://dx.doi. org/10.1016/j.landurbplan.2003.08.011

Haddad, N. M., L. A. Brudvig, J. Clobert, K. F. Davies, A. Gonzalez, R. D. Holt, T. E. Lovejoy, J. O. Sexton, M. P. Austin, C. D. Collins, et al. 2015. Habitat fragmentation and its lasting impact on Earth's ecosystems. Science Advances 1(2):e1500052. http://dx.doi.org/10.1126/sciadv.1500052 
Houde, N. 2007. The six faces of traditional ecological knowledge: challenges and opportunities for Canadian co-management arrangements. Ecology and Society 12(2):34. http://dx.doi. org/10.5751/ES-02270-120234

Kroll, J. C., D. C. Guynn Jr, and G. L. Alt. 2012. Final report and recommendations, Wisconsin White-tailed Deer Trustee and Review Committee. Wisconsin Department of Natural Resources, Madison, Wisconsin, USA. [online] URL: http://dnr.wi.gov/ topic/wildlifehabitat/documents/trusteereport.PDF

Kurtz, C. M., W. K. Moser, M. H. Hansen, D. D. Gormanson, M. A. Hatfield, P. A. Sowers, M. J. Dockry, M. R. Emery, C. W. Woodall, B. F. Walters, and G. M. Domke. 2015. Forest resources within the Lake States ceded territories 1980-2013. U.S. Forest Service Technical Report \#96. U.S. Forest Service, Newtown Square, Pennsylvania, USA.

Leopold, A. 1933. Game management. Charles Scribner's Sons, New York, New York, USA.

Lepofsky, D., C. G. Armstrong, S. Greening, J. Jackley, J. Carpenter, B. Guernsey, D. Mathews, and N. J. Turner. 2017. Historical ecology of cultural keystone places of the Northwest Coast. American Anthropologist 119(3):448-463. http://dx.doi. org/10.1111/aman.12893

Luyssaert, S., E.-D. Schulze, A. Börner, A. Knohl, D. Hessenmöller, B. E. Law, P. Ciais, and J. Grace. 2008. Old-growth forests as global carbon sinks. Nature 455:213-215. http://dx.doi. org/10.1038/nature07276

Marquardt, K., R. Milestad, and L. Salomonsson. 2013. Improved fallows: a case study of an adaptive response in Amazonian swidden farming systems. Agriculture and Human Values 30(3):417-428. http://dx.doi.org/10.1007/s10460-012-9415-5

McCorquodale, S. M. 1997. Cultural contexts of recreational hunting and native subsistence and ceremonial hunting: their significance for wildlife management. Wildlife Society Bulletin 25 (2):568-573.

McKinney, M. L. 2002. Urbanization, biodiversity, and conservation. BioScience 52:883-890. http://dx.doi.org/10.1641/0006-3568 (2002)052[0883:UBAC]2.0.CO;2

McShea, W. J., and J. H. Rappole. 2000. Managing the abundance and diversity of breeding bird populations through manipulation of deer populations. Conservation Biology 14:1161-1170. http:// dx.doi.org/10.1046/j.1523-1739.2000.99210.x

Millspaugh, J. J., J. R. Skalski, R. L. Townsend, D. R. Diefenbach, M. S. Boyce, L. P. Hansen, and K. Kammermeyer. 2009. An evaluation of sex-age-kill (SAK) model performance. Journal of Wildlife Management. 73(3):442-451. http://dx.doi.org/10.2193/2008-099

Mortensen, D. A., E. S. J. Rauschert, A. N. Nord, and B. P. Jones. 2009. Forest roads facilitate the spread of invasive plants. Invasive Plant Science and Management 2:191-199. http://dx.doi. org/10.1614/IPSM-08-125.1

Nesper, L. 2002. The walleye war: the struggle for Ojibwe spearfishing and treaty rights. University of Nebraska Press, Lincoln, Nebraska, USA.

Nolte, C., A. Agrawal, K. M. Silvius, and B. S. Soares-Filho. 2013. Governance regime and location influence avoided deforestation success of protected areas in the Brazilian Amazon. Proceedings of the National Academy of Sciences 110(13):4956-4961. http:// dx.doi.org/10.1073/pnas. 1214786110

Ostrom, E., M. A. Janssen, and J. M. Anderies. 2007. Going beyond panaceas. Proceedings of the National Academy of Sciences 104(39):15176-15178. http://dx.doi.org/10.1073/pnas.0701886104

Parlee, B., and F. Berkes, and the Teetl'it Gwich'in Renewable Resources Council. 2005a. Health of the land, health of the people: a case study on Gwich'in berry harvesting in northern Canada. EcoHealth 2(2):127-137. http://dx.doi.org/10.1007/ $\underline{\mathrm{s} 10393-005-3870-\mathrm{Z}}$

Parlee, B., M. Manseau, and Łutsël K'é Dene First Nation. $2005 b$. Using traditional knowledge to adapt to ecological change: Denésǫłıné monitoring of Caribou movements. Arctic 58:26-37.

Pecore, M. 1992. Menominee sustained-yield management: a successful land ethic in practice. Journal of Forestry 90(7):2-16.

Peres, C. A. 1994. Indigenous reserves and nature conservation in Amazonian forests. Conservation Biology 8(2):586-588. http:// dx.doi.org/10.1046/j.1523-1739.1994.08020586.X

Perry, C. H., V. A. Everson, I. K. Brown, J. Cummings-Carlson, S. E. Dahir, E. A. Jepsen, J. Kovach, M. D. Labissoniere, T. R. Mace, E. A. Padley, R. B. Rideout, B. J. Butler, S. J. Crocker, G. C. Liknes, R. S. Morin, M. D. Nelson, B. T. Wilson, and C. W. Woodall. 2008. Wisconsin's forests 2004. NRS-23, U.S. Forest Service, Northern Research Station, Newtown Square, Pennsylvania, USA.

Perry, C. H., V. A. Everson, B. J. Butler, S. J. Crocker, S. E. Dahir, A. L. Diss-Torrance, G. M. Domke, D. D. Gormanson, S. K. Herrick, S. S. Hubbard, T. R. Mace, P. D. Miles, M. D. Nelson, R. B. Rideout, L. K. Saunders, K. M. Stueve, and B. T. Wilson, C. W. Woodall. 2012. Wisconsin's forests 2009. NRS-67, U.S. Forest Service, Northern Research Station, Newtown Square, Pennsylvania, USA.

Pickett, S. T. A., and J. N. Thompson. 1978. Patch dynamics and the design of nature reserves. Biological Conservation 13:27-37. http://dx.doi.org/10.1016/0006-3207(78)90016-2

Pinkerton, E. 1989. The future of fisheries co-management: a multidisciplinary assessment. Co-operative management of local fisheries: new directions for improved management and community development. University of British Columbia Press, Vancouver, British Columbia, Canada.

Radeloff, V. C., R. B. Hammer, and S. I. Stewart. 2005. Rural and suburban sprawl in the U.S. Midwest from 1940 to 2000 and its relation to forest fragmentation. Conservation Biology 19 (3):793-805. http://dx.doi.org/10.1111/j.1523-1739.2005.00387.x

Redford, K. H., and A. M. Stearman. 1993. Forest-dwelling Native Amazonians and the conservation of biodiversity: interests in common or in collision? Conservation Biology 7 (2):248-255. http://dx.doi.org/10.1046/j.1523-1739.1993.07020248. $\underline{\mathrm{X}}$

Reo, N. J., and J. W. Karl. 2010. Tribal and state ecosystem management regimes influence forest regeneration. Forest Ecology and Management 260:734-743. http://dx.doi.org/10.1016/ j.foreco.2010.05.030 
Reo, N. J., and K. P. Whyte. 2012. Hunting and morality as elements of traditional ecological knowledge. Human Ecology 40 (1):15-27. http://dx.doi.org/10.1007/s10745-011-9448-1

Ripple, W. J., and R. L. Beschta. 2005. Linking wolves and plants: Aldo Leopold on trophic cascades. Bioscience 55:613-621. http:// dx.doi.org/10.1641/0006-3568(2005)055[0613:LWAPAL]2.0.CO;2

Rogers, D. A., T. P. Rooney, T. J. Hawbaker, V. C. Radeloff, and D. M. Waller. 2009. Paying the extinction debt in southern Wisconsin forest understories. Conservation Biology 23:1497-1506. http://dx.doi.org/10.1111/j.1523-1739.2009.01256.x

Rooney, T. P., R. J. McCormick, S. L. Solheim, and D. M. Waller. 2000. Regional variation in recruitment of hemlock seedlings and saplings in the Upper Great Lakes, USA. Ecological Applications 10:1119-1132. http://dx.doi.org/10.1890/1051-0761(2000)010[1119: $\underline{\text { RVIROH]2.0.CO;2 }}$

Rooney, T. P., S. L. Solheim, and D. M. Waller. 2002. Factors affecting the regeneration of northern white cedar in lowland forests of the Upper Great Lakes region, USA. Forest Ecology and Management 163:119-130. http://dx.doi.org/10.1016/S0378-1127 (01)00532-1

Rooney, T. P., and D. M. Waller. 1998. Local and regional variation in hemlock seedling establishment in forests of the upper Great Lakes region, USA. Forest Ecology and Management 111:211-224. http://dx.doi.org/10.1016/S0378-1127(98)00333-8

Rooney, T. P., and D. M. Waller. 2003. Direct and indirect effects of white-tailed deer in forest ecosystems. Forest Ecology and Management 181:165-176. http://dx.doi.org/10.1016/S0378-1127 (03)00130-0

Rooney, T. P., S. M. Wiegmann, D. A. Rogers, and D. M. Waller. 2004. Biotic impoverishment and homogenization in unfragmented forest understory communities. Conservation Biology 18:787-798. http://dx.doi.org/10.1111/j.1523-1739.2004.00515. $\underline{\mathrm{x}}$

Sayles, J. S., and M. E. Mulrennan. 2010. Securing a future: Cree hunters' resistance and flexibility to environmental changes, Wemindji, James Bay. Ecology and Society 15(4):22. http://dx.doi. org/10.5751/ES-03828-150422

Slik, J. W. F., S. I. Aiba, F. Q. Brearley, C. H. Cannon, O. Forshed, K. Kitayama, H. Nagamasu, R. Nilus, J. Payne, G. Paoli, et al. 2010. Environmental correlates of tree biomass, basal area, wood specific gravity and stem density gradients in Borneo's tropical forests. Global Ecology and Biogeography 19:50-60. http://dx.doi. org/10.1111/j.1466-8238.2009.00489.x

Spellerberg, I. F. 1998. Ecological effects of roads and traffic: a literature review. Global Ecology and Biogeography Letters 7:317-333. http://dx.doi.org/10.2307/2997681

Steen-Adams, M. M., D. J. Mladenoff, N. E. Langston, F. Liu, and J. Zhu. 2011. Influence of biophysical factors and differences in Ojibwe reservation versus Euro-American social histories on forest landscape change in northern Wisconsin, USA. Landscape Ecology 26:1165. http://dx.doi.org/10.1007/s10980-011-9630-2

Stevens, S. 2014. Indigenous peoples, national parks, and protected areas: a new paradigm linking conservation, culture, and rights. University of Arizona Press, Tucson, Arizona, USA.
Swift, E. 1948. Wisconsin deer damage to forest reproduction survey: final report. Wisconsin Conservation Department, Madison, Wisconsin, USA.

Torres, A. B., and J. C. Lovett. 2013. Using basal area to estimate aboveground carbon stocks in forests: La Primavera Biosphere's Reserve, Mexico. Forestry 86:267-281. http://dx.doi.org/10.1093/ forestry/cps084

Treves, A., and J. T. Bruskotter. 2014. Tolerance for predatory wildlife. Science 344:476-477. http://dx.doi.org/10.1126/science.1252690

Trombulak, S. C., and C. A. Frissell. 2000. Review of ecological effects of roads on terrestrial and aquatic communities. Conservation Biology 14:18-30. http://dx.doi.org/10.1046/ j.1523-1739.2000.99084.X

Trosper, R. L. 2007. Indigenous influence on forest management on the Menominee Indian Reservation. Forest Ecology and Management 249(1-2):134-139. http://dx.doi.org/10.1016/j. foreco.2007.04.037

Usik, K. A. 2015. The hunt for Ma'iingan: Ojibwe ecological knowledge and wolf hunting in the Great Lakes. Thesis. University of Iowa, Iowa City, Iowa, USA.

Van Deelen, T. R., B. J. Dhuey, C. N. Jacques, K. R. McCaffery, R. E. Rolley, and K. Warnke. 2010. Effects of earn-a-buck and special antlerless-only seasons of Wisconsin's deer harvests. Journal of Wildlife Management 74:1693-1700. http://dx.doi. org/10.2193/2009-551

Waller, D. M. 2008. The big picture. Pages 465-476 in D. M. Waller and T. P. Rooney, editors. The vanishing present: Wisconsin's changing lands, waters, and wildlife. University of Chicago Press, Chicago, Illinois, USA. http://dx.doi.org/10.7208/ chicago/9780226871745.003.0032

Waller, D. M. 2014. Effects of deer on forest herb layers. Pages 369-399 in F. S. Gilliam, editor. The herbaceous layer in forests of Eastern North America. Second edition. Oxford University Press, Oxford, UK. http://dx.doi.org/10.1093/acprof:osobl/978019983$\underline{7656.003 .0016}$

Waller, D. M., and W. S. Alverson. 1997. The white-tailed deer: a keystone herbivore. Wildlife Society Bulletin 25:217-226.

Warren, D. M., and J. Pinkston. 1998. Indigenous African resource management of a tropical rainforest ecosystem: a case study of the Yoruba of Ara, Nigeria. Pages 158-189 in F. Berkes and C. Folke, editors. Linking social and ecological systems: management practices and social mechanisms for building resilience. Cambridge University Press, Cambridge, UK.

Wiegmann, S. M., and D. M. Waller. 2006. Fifty years of change in northern upland forest understories: identity and traits of "winner" and "loser" plant species. Biological Conservation 129:109-123. http://dx.doi.org/10.1016/j.biocon.2005.10.027

Willging, R. C. 2008. On the hunt: the history of deer hunting in Wisconsin. Wisconsin Historical Society Press, Madison, Wisconsin, USA.

Williams, E. T. 1967. State guides for assessing forest land and timber, 1966. U.S. Forest Service, Misc. Publ. 1061. U.S. Government Printing Office, Washington, D.C., USA. 
Wisconsin Department of Natural Resources. 2011. Wisconsin forest management guidelines. PUB-FR-226 2011. Wisconsin Department of Natural Resources, Madison, Wisconsin, USA. [online] URL: http://dnr.wi.gov/topic/forestmanagement/guidelines. $\underline{\text { html }}$

Wisconsin Department of Natural Resources. 2017. Deer abundance and densities in Wisconsin deer management units. Wisconsin Department of Natural Resources, Madison, Wisconsin, USA. [online] URL: https://dnr.wi.gov/topic/hunt/ maps.html

Yazzie, V. 2007. The tribal perspective of old growth in frequentfire forests - its history. Ecology and Society 12(2):21. http://dx. doi.org/10.5751/ES-02252-120221 